\title{
Strategic supplier selection using multi-stakeholder and multi-perspective approaches
}

\author{
William Ho \\ Department of Management and Marketing \\ The University of Melbourne \\ Level 10, 198 Berkeley Street \\ Victoria 3010, Australia \\ Email address: william.ho@unimelb.edu.au \\ Prasanta Kumar Dey \\ Operations \& Information Management Group \\ Aston Business School \\ Aston University \\ Birmingham B4 7ET, United Kingdom \\ Email address: p.k.dey@aston.ac.uk \\ Arijit Bhattacharya \\ Brunel Business School, Brunel University, Kingston Lane \\ Uxbridge, Middlesex, UB8 3PH, United Kingdom \\ Email address: arijit.bhattacharya2005@gmail.com
}

\section{Introduction}

Supply management is one of the key issues of manufacturing supply chain management because the costs of raw materials and component parts constitute the main cost of a product, and most firms spend considerable amounts of their sales revenues on purchasing. Goffin et al. (2006) suggest that supplier selection is one of the most important decision making problems in supply management. Ghodsypour and O’Brien (2001) find that selecting the right supplier significantly reduces the purchasing costs and improves corporate competitiveness. Therefore, appropriate supplier selection improves supply chain performance.

Strategic supplier selection is different from the conventional low-cost and one-off supplier selection. Increasingly organizations are pursuing long-term relationships with their suppliers for strategic and crucial items with a view to soliciting insights for new product development and resolving various operational issues. The selection of appropriate suppliers involves consideration of multiple quantitative and qualitative criteria other than price (Ho et al., 2010). Strategic supplier selection should involve multiple internal stakeholders (e.g., quality, manufacturing, finance, marketing etc.) and external stakeholders (e.g., national/local government, policy makers, environmental groups, community/public etc.) rather than the purchasing and supply management function in isolation. The active involvement of concerned stakeholders would lead to a balanced consideration of multiple and conflicting voices of customers and provide a mechanism to communicate tacit knowledge - knowledge that is known by one individual or department that may not otherwise be communicated through the organization. Therefore, the multi-stakeholder and multi-perspective approaches help supply management personnel understand the essential requirements from various departments and make the sourcing decisions more effective (Ho et al., 2011).

Selecting strategic suppliers without taking a holistic perspective of all the stakeholders concerned would have a negative impact on supply chain performance. For example, the 
common practice of the bioenergy sector is to make decisions on biomass supplier selection solely by technical experts, who focus on finding the optimal solution in a cost-efficient manner, but neglect holistic planning and stakeholder support. The opinions and perspectives of the concerned stakeholders across the bioenergy supply chain are rarely considered or they are only considered after the suppliers have been selected, and the result is often the failure of a project (Scott et al., 2013).

Various approaches that can deal with multiple and conflicting criteria in decision making have been proposed and applied extensively in the academic literature (Weber et al., 1991; Degraeve et al., 2000; De Boer et al., 2001; Ho et al., 2010; Chai et al., 2013). However, few of them consider the impact of company strategies and the perspectives of company stakeholders in relation to the identification of suitable criteria for strategic supplier selection. Hence, the selected suppliers would not be able to meet long-term business objectives. In addition, most of such approaches are theoretical in nature and have not been empirically validated.

This special issue of the International Journal of Production Economics aims to provide a platform for sharing novel and potential multi-stakeholder and multi-perspective approaches for strategic supplier selection. Among 64 submissions, we accepted ten papers presenting new and significant research in this area, and they are classified into analytical and empirical approaches.

\section{Analytical approaches}

The paper, "Developing green purchasing relationships for the manufacturing industry: An evolutionary game theory perspective” by $\mathrm{Ji}$ et al. (in press), updates the supplier selection concept model suggested by de Boer and develops an evolutionary game model to observe the cooperation tendency of multi-stakeholders (suppliers and manufacturers) and establish long-term green purchasing relationships between them. The model was tested in a Hong Kong based toy manufacturing company. Their findings, based on the simulation experiments, show that the manufacturing industry can form the patterns of sustainable development, and the recycling capability of suppliers directly determines how green a supply chain is.

In the paper "Service supply chain environmental performance evaluation using grey based hybrid MCDM approach" by Chithambaranathan et al. (in press), the analytical framework integrates grey based method with ELECTRE and VIKOR approaches to evaluate environmental performance of service supply chains in a developing country context. The framework was implemented in two case studies, including the medical support service providers and catering service providers, to understand the effectiveness of the evaluation criteria and method. The paper does not mention which stakeholders or decision makers were involved in the evaluation and selection processes.

The paper, "Supplier selection for sustainable operations: A triple-bottom-line approach using a Bayesian Framework" by Sarkis and Dhavale (in press), applies a Bayesian framework and Monte Carlo Markov Chain simulation to rank and select suppliers with respect to the triple-bottom-line objectives (profit, people, and planet). Their findings show that the approach is also effective when smaller or missing data sets exist, and the model allows the decision maker to execute various scenarios by changing importance weights attached to the objectives. The paper does not tell which stakeholder groups were involved in the evaluation and selection processes, and uses hypothetical data for testing the model. 
In the paper "Strategic supplier performance evaluation: A case-based action research of a UK manufacturing organisation" by Dey et al. (in press), the analytical framework integrates the analytic hierarchy process approach with a series of three houses of quality to translate the requirements of various stakeholder groups (financial, procurement, production, quality, technical, and marketing departments, and top management) into leading and lagging evaluation criteria for benchmarking the potential suppliers in a UK based carpet manufacturing company. The effectiveness of the method has been demonstrated through number of validations (e.g., focus groups, business results, and statistical analysis).

The paper, "Multi-perspective strategic supplier selection in uncertain environments" by Chai and Ngai (in press), proposes a soft decision model for strategic supplier selection in uncertain decision environments. Founded on interval and hesitant fuzzy methodology, the proposed model is capable of handling ambiguous judgments of stakeholders and unbiased value preservation of conflicting opinions. The model also ensures that the selection process strictly conforms to the diverse strategies of the company and is applicable for a flexible number of stakeholders. The paper illustrates the model via a case in a global computer, communication, and consumer electronics products manufacturing company, in which the stakeholder groups are not specified.

In the paper "A decision support system for supplier selection and order allocation in stochastic, multi-stakeholder and multi-criteria environments" by Scott et al. (in press), the decision support system integrates analytic hierarchy process, quality function deployment, and chance constrained optimization algorithm approach to select appropriate suppliers with respect to multiple requirements of various stakeholders, and allocate orders optimally between the suppliers with uncertain supply characteristics and with non-crisp constraints. The paper demonstrates the efficacy of the proposed model by applying it to the biomass for energy supplier selection problem, in which the stakeholders identified are financial groups, environmental groups, developers, national government, local government, and community.

\section{Empirical approaches}

The paper, "Strategic sourcing supplier selection misalignment with critical success factors: Findings from multiple case studies in Germany and the United Kingdom” by Kotula et al. (in press), conducts twenty case studies to qualitatively evaluate and understand the current role of strategic sourcing, the critical success factors for business performance and its relationship with strategic sourcing, and strategic supplier evaluation criteria from multiple stakeholders' perspectives specific to industry and country. The paper considers five organisations from each industry sector (electronics manufacturing and construction) and each country (Germany and the UK). Based on the comparative analysis of twenty case studies, seven research propositions are derived.

The paper, "Strategic sourcing with multi-stakeholders through value co-creation: An evidence from global health care company" by Nudurupati et al. (in press), conducts a case study to understand the process of value co-creation in a service context. The paper shows how a global health care company uses the Kraljic portfolio purchasing matrix for initial screening of potential suppliers, identifies multiple internal and external stakeholders, mediates their goals to establish behavioural factors for strategic supplier selection, and evaluates the effectiveness of multi-stakeholder collaborative decision-making during the process to develop a value co-creation system. 
The paper, “Antecedents of buyer opportunistic behavior in outsourcing relationships" by Bhattacharya et al. (in press), based on the transaction cost economics theory, tests a model consisting of three factors that could give rise to buyer opportunism with dyadic data from 51 outsourcing arrangements between firms in Australia using the multiple regression analysis. Among the three factors, only "frequency of exchange" has a significant and positive effect on buyer opportunism, whereas "investments made by suppliers" and "uncertainty" are not significant. Their results suggest that buyers' opportunism can be controlled by the frequency of transactions that takes place.

The paper, "Sourcing complexity in the Chinese manufacturing sector: An assessment of intangible factors and contractual relationship strategies" by Subramanian et al. (in press), deploys the importance-complexity matrix analysis with a sample of 101 original equipment manufacturers based in China to investigate the impact of intangible factors on sourcing complexity. Their findings show that lack of knowledge, quality issues, price erosion, increase in comparative price levels, supply risk, and demand volatility are the most critical intangible factors contributing to the sourcing complexity. The paper suggests appropriate supplier contractual strategies, such as collaborative relationships, would suppress or greatly diminish most of the intangible sourcing complexity factors.

To conclude, we are most grateful to all the authors for their contribution, and all the reviewers for their constructive comments, which made this special issue possible. We would like to thank Professor Edwin Cheng (Asian-Pacific Editor of the International Journal of production Economics) for helping us and providing us constructive advice from an early stage to the project completion. We would also like to acknowledge three staff of the International Journal of production Economics for their continuous support, including Marian Paul, Rukmani Krishnan, and Thiyagarajan Boopathy. We hope that this special issue would contribute significantly to the context of strategic supplier selection.

\section{References}

Bhattacharya, A., Signh, P.J., Nand, A.A. (in press). Antecedents of buyer opportunistic behavior in outsourcing relationships. International Journal of Production Economics.

Chai, J., Liu, J.N.K., Ngai, E.W.T. (2013). Application of decision-making techniques in supplier selection: A systematic review of literature. Expert Systems with Applications 40 (10), 3872-3885.

Chai, J., Ngai, E.W.T. (in press). Multi-perspective strategic supplier selection in uncertain environments. International Journal of Production Economics.

Chithambaranathan, P., Subramanian, N., Gunasekaran, A., Palaniappan, P.L.K. (in press). Service supply chain environmental performance evaluation using grey based hybrid MCDM approach. International Journal of Production Economics.

De Boer, L., Labro, E., Morlacchi, P. (2001). A review of methods supporting supplier selection. European Journal of Purchasing and Supply Management 7 (2), 75-89.

Degraeve, Z., Labro, E., Roodhooft, F. (2000). An evaluation of supplier selection methods from a total cost of ownership perspective. European Journal of Operational Research 125 (1), 34-58.

Dey, P.K., Bhattacharya, A., Ho, W. (in press). Strategic supplier performance evaluation: A case-based action research of a UK manufacturing organisation. International Journal of Production Economics. 
Ghodsypour, S.H., O’Brien, C. (2001). The total cost of logistics in supplier selection, under conditions of multiple sourcing, multiple criteria and capacity constraint. International Journal of Production Economics 73, 15-27.

Goffin, K., Lemke, F., Szwejczewski, M. (2006). An exploratory study of 'close' suppliermanufacturer relationships. Journal of Operations Management 24, 189-209.

Ho, W., Xu, X., Dey, P.K. (2010). Multi-criteria decision making approaches for supplier evaluation and selection: a literature review. European Journal of Operational Research 202, 16-24.

Ho, W., Dey, P.K., Lockström, M. (2011). Strategic sourcing: A combined QFD and AHP approach in manufacturing. Supply Chain Management: An International Journal 16, 446-461.

Ji, P., Ma, X., Li, G. (in press). Developing green purchasing relationships for the manufacturing industry: An evolutionary game theory perspective. International Journal of Production Economics.

Kotula, M., Ho, W., Dey, P.K., Lee, C.K.M. (in press) Strategic sourcing supplier selection misalignment with critical success factors: Findings from multiple case studies in Germany and the United Kingdom. International Journal of Production Economics.

Nudurupati, S., Bhattacharya, A., Lascelles, D., Caton, N. (in press). Strategic sourcing with multi-stakeholders through value co-creation: An evidence from global health care company. International Journal of Production Economics.

Sarkis, J., Dhavale, D.G. (in press). Supplier selection for sustainable operations: A triplebottom-line approach using a Bayesian Framework. International Journal of Production Economics.

Scott, J.A., Ho, W., Dey, P.K. (2013). Strategic sourcing in the UK bioenergy industry. International Journal of Production Economics 146, 478-490.

Scott, J.A., Ho, W., Dey, P.K., Talluri, S. (in press) A decision support system for supplier selection and order allocation in stochastic, multi-stakeholder and multi-criteria environments. International Journal of Production Economics.

Subramanian, N., Rahman, S., Abdulrahman, M.D. (in press). Sourcing complexity in the Chinese manufacturing sector: An assessment of intangible factors and contractual relationship strategies. International Journal of Production Economics.

Weber, C.A., Current, J.R., Benton, W.C. (1991). Vendor selection criteria and methods. European Journal of Operational Research 50, 2-18. 


\section{University Library}

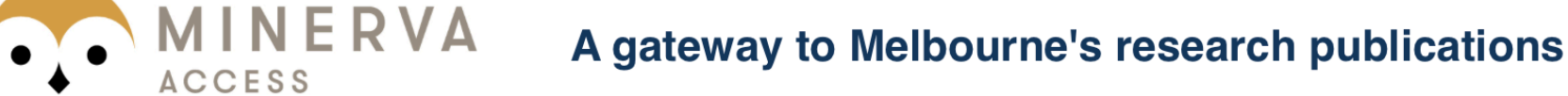

Minerva Access is the Institutional Repository of The University of Melbourne

Author/s:

Ho, W;Dey, PK;Bhattacharya, A

Title:

Strategic supplier selection using multi-stakeholder and multi-perspective approaches

Date:

2015-08-01

Citation:

Ho, W., Dey, P. K. \& Bhattacharya, A. (2015). Strategic supplier selection using multi-

stakeholder and multi-perspective approaches. INTERNATIONAL JOURNAL OF

PRODUCTION ECONOMICS, 166, pp.152-154. https://doi.org/10.1016/j.ijpe.2015.03.028.

Persistent Link:

http://hdl.handle.net/11343/118653 